\title{
10
}

\section{The Colonial Legacies of Copper Dependence: Inequality and Bifurcated Social Protection in Zambia}

\section{Anna Wolkenhauer}

\section{Introduction}

There is a growing consensus that colonial legacies need to be factored into analyses of African social protection and welfare regimes (Mkandawire 2016). While different institutional set-ups and social ideologies might have left their marks until the present day, I argue that another crucial legacy that has influenced subsequent social policies merits more attention: The way in which former colonies were integrated into the world economy. This shifts our focus onto the social questions that arose from colonial exploitation, and the ways these were politically addressed in subsequent years. Samir Amin (1972) has offered a broad typology of African countries that is as relevant today as it was at the time of its publication, and the chapter at hand delves into, in Amin's words, one of the former "labour reserve economies" (Amin 1972, 519). The chapter focusses on Zambia, a British colony until 1964, for understanding how

\footnotetext{
A. Wolkenhauer $(\varpi)$

University of Bremen, Bremen, Germany

e-mail: anna.wolkenhauer@uni-bremen.de 
colonial economic legacies have been able to shape the development of social protection systems even after formal independence.

The chapter identifies two overall mechanisms. Firstly, the dependence of the Zambian economy on copper exports, which was ushered-in during the colonial era, has left the state's budget highly vulnerable to world market copper prices. This has not only created public finance constraints but also led to a concentration of economic activities in a narrow geographical area that has remained inaccessible to most citizens so that wealth has not been broadly shared (Hinfelaar and Archberger 2017). Secondly, the enclave character of mining and industrial activity has equally resulted in an enclave structure of political organisation and representation. This has manifested itself in a bifurcation of demand-driven social insurance in the centres, and supply-driven social assistance in the peripheries (Kumitz 2016). While in the new millennium, targeted social assistance programmes, such as a cash transfer, have been scaled up, employment-based social insurance schemes, such as old-age pensions, remain limited to the small formal workforce. ${ }^{1}$ This helps to understand how the country's dependence on an enclave copper sector has remained an obstacle for a state-led, broad-based and adequate social protection system ever since (Mhone 2004). In the following, the colonial impact on Zambia's economic structure is briefly introduced, after which the two identified mechanisms are further described.

\section{The Colonial Legacy of the Copper Enclave Economy}

During Zambia's colonial occupation, first by the British South Africa Company (BSAC) and then by the British Colonial Office, the foundation was laid for a stark centre-periphery divide that has lasted up until the present. $^{2}$ The origin of this was the opening of several large copper

\footnotetext{
${ }^{1}$ Social insurance schemes cover around 10 percent of the working-age population and their dependants (Barrientos et al. 2005, 23).

${ }^{2}$ The resulting centre-periphery inequality somewhat overlapped with an urban-rural distinction, but due to fast urbanisation without sufficient employment opportunities as well as rural class differentiation, there is also a periphery in the urban centres and a centre in the rural periphery.
} 
mines, owned by British, South African, and American companies, in the early 1930s, which led to the geographical concentration of economic activities along the so-called Line of Rail. Besides mining, industries and commercial agriculture also came to be focused there, as production linkages were created close by. For feeding the mine and industry workers, large-scale agriculture was practised by European commercial farmers, who established powerful links with the colonial government. To facilitate this system, the latter supported Europeans' access to good soils. Thereby, a further distinction was initiated: On the one hand, good and accessible land was reserved for the European settlers, while on the other hand, Africans were forced to move to more remote and, by and large, less fertile land. This was underpinned by a dual legal land administration system and, in combination, this era created not only an enclave-like economy but also a lasting inequality within the rural sector.

Zambia was ruled without the willingness to invest much money and profit-making was the priority of both the BSAC and the Colonial Office. The emerging mining sector needed migrant labour, for which Africans were forced out of rural areas by varying means of coercion and driven by the need to earn a wage. This resulted in a further long-term deterioration of rural livelihoods (Mhone 2004, 315-16). Meanwhile, the mines paid their royalties and tax in London (Roberts 1976, 186-93). Social security was granted to organised European employees in the mines, and to African mine workers once they had become more politically vocal in the late colonial period, especially after the Second World War (WWII). Schemes for smallholders were initiated in that period, too, but were limited in geographical reach and overall coverage, and tended to be biased towards better connected farmers, thereby creating a differentiation among African farmers (Momba 1985). At independence, hence, there was a bifurcation between workers at the centre with formal social security coverage, and the majority of citizens in the periphery who had fallen through the cracks. These were the initial conditions that the new state faced in 1964. In Zambia, as in many African countries, a window of opportunity for structurally transformative state interventions existed in the early years following independence, thanks to a favourable ideational and economic international environment (Mkandawire 1988). This, however, ended very soon when, from the mid-1970s, a mutually 
reinforcing mixture of economic crises and neoliberal reforms began to sustainably undermine the capacity of the state to significantly transform socio-economic conditions.

\section{A Short Post-Independence Window of Opportunity}

In the years following political independence, the United National Independence Party (UNIP) government under President Kenneth Kaunda undertook several interventions aimed at improving the socioeconomic situation of the population. It nationalised the copper sector, set up new industries across the territory and invested in agricultural productivity. These measures were underpinned by an ideology of "Humanism" that revolved around nationalism, solidarity, communalism and a mixture of liberalism and socialism (Bowman 2011, 95), and enabled by favourable terms of trade and relatively high gross domestic product (GDP). Between 1964 and 1969, real annual growth stood at an average of 10.9 percent, largely thanks to copper exports (UNCTAD 2016, 2), and hopes among the population were high (Ferguson 1999). The task of changing the inherited structures, however, was enormous and several challenges impeded success.

In the first five years after independence, the copper mines were still in foreign companies' hands, but the government started to take the royalties, raised income tax and introduced an export tax, so that it eventually earned around three-quarters of the mines' profits (Roberts 1976, 230-31). This, however, disincentivised the mining companies from making substantial investments, which is why Kaunda declared in 1969 that the mining industry would be nationalised in order to be better able to carry out mining policy decisions and to prioritise long-term investments. The government bought 51 percent shares of the companies, which it promised to repay from the revenue that was soon to be expected considering the good world copper prices in the second half of the 1960s. The government also took back the mining rights from the companies as well as rights for future explorations (Roberts 1976, 230-31). 
Unfortunately, between 1970 and 1974, the price of copper per tonne dropped from 748 British pounds to 500, and, moreover, the attempt to set up an Organization of the Petroleum Exporting Countries (OPEC)like alliance between copper exporters, that could have stabilised world prices, was ineffective due to a limited number of members (Larmer 2010,40 ). The period in which copper was able to finance public policy was hence short.

Some economic diversification was achieved in the first years after independence, and the value of manufacturing grew threefold between 1964 and 1968 (Roberts 1976, 232). But costs for setting up new industries were high as Zambia incurred high trading costs due to being landlocked and depending on routes through neighbouring countries where liberation struggles were going on (Roberts 1976, 232). Most state enterprises and import substitution focused on consumer goods such as textiles or beverages, as well as chemicals, plastics and rubber (Lombe 2018, 5). Where they were set up outside the usual centres, industrial plants incurred high transport costs and faced severe market constraints (e.g. Peša 2014, 95). Moreover, the new income opportunities were not equally shared but tended to accrue to those who already had some links to privileged strata such as through colonial education or the new state structures (Baylies and Szeftel 1982). Business owners often came from within the state, so that a "bureaucratic bourgeoisie" emerged (Seidman $1979,43)$. Thus, in the first years after independence, the formerly white ruling and business elite had been replaced with an emerging class of wealthy Africans, who had better access to the new social and economic infrastructure (Seidman 1979, 44).

In agriculture, some progress in productivity was achieved, too, but smallholder farmers struggled with poor soils, a lack of technical knowledge and the need for expensive machinery (Roberts 1976, 233). Production was still concentrated in 400 commercial farms that were largely still owned by expats, and efficient and marketable African production remained confined-again - to the better-off Southern, Eastern and Central Provinces (Roberts 1976, 233). While Kaunda appealed with great conviction to the cooperative spirit among smallholders and invested in primary producer societies with an adjacent multi-layer apex body, actual spending on rural development was limited, as mining 
revenue was reinvested in the mining sector itself as well as in the Line of Rail region (Larmer 2010). In this time, remittances were an important informal redistributive mechanism between the centres and the rural periphery (Larmer 2010). Interventions such as the Agricultural Marketing Board, created in 1969, were meant to keep consumer prices for food low and benefited the mine and industry workers (Chiwele et al. 1996, 7-8), who, it was feared, would otherwise have been in a position to threaten the peace in the country's economic centres (Bowman 2011, 21). Nonetheless, the Marketing Board and the state-created cooperatives did provide an important social contract between the state and smallscale farmers as they offered some income security, and access to transport and storage (Putzel and DiJohn 2012, 14). Because the Marketing Board made losses from this arrangement, the government, however, began to incur debt and the arrangement was not sustainable in the long run.

Overall, the social question posed by urban-rural inequality was not resolved during the early post-independence period. In fact, as productivity did not rise as fast as the cost of living in the countryside, inequality even increased during this period, and the peasantry began to feel left out of the nationalist project (Muntemba 1978, 85). Where Africans took over jobs vacated by Europeans, they also took over the relatively higher wages, while in more outlying areas, people lived at "sub-subsistence levels" (Roberts 1976, 235). Eventually, in the mid-1970s, the economic basis of the state began to be eroded as the oil price rose and copper prices fell. The average annual growth rate dropped to 1.5 percent in the $1970 \mathrm{~s}$, 1.4 percent in the 1980 s and 0.2 percent in the 1990s (UNCTAD 2016, 2). Zambia thus had to enter into several loan agreements with the International Monetary Fund (IMF) and structural adjustment programmes with the World Bank; and since then, the international financial institutions "have tightly policed Zambia's economic policies" (Fraser and Lungu 2007, 9). In combination with limited budgets, neoliberal policy prescriptions effectively dismantled the state's ability to increase economic opportunities and support formal employment creation as a basis for broad social insurance coverage. 


\section{Demand-Driven and Supply-Driven Social Protection}

The above has shown how short the window of opportunity was for the Zambian government to solve the social questions created by colonial exploitation. But the inherited economic dualism, with a concentration of wealth in a few centres, was also manifested through a second mechanism. Social policies and their uneven distribution have been locked-in through feedback effects with uneven political organisation. Workers at the centre (first Europeans, later Africans) have always been relatively well organised and able to make demands, while the dispersed peasantry remained dependent on benign schemes thought out at the centre and implemented in a supply-driven manner. This began in the colonial era, when the economic dualism, at first an unconscious process driven by "economic and autonomous factors", was further entrenched by economic interest groups that emerged, and who lobbied the colonial government to maintain the status quo and protect their privileged access to resources (Mhone 1982, 25).

During the late colonial phase, African mine workers' unions became more vocal and powerful. They were able to make demands on the mining companies, who were forced to provide a limited amount of social services (Larmer 2010, 34). During the anti-colonial struggle, miners retained their specific identity as mine workers, rather than letting the nationalist movement subsume them for overall national development, and retained their specific lobbying power also vis-à-vis the Kaunda government. The government, in turn, was torn between giving in to their demands-knowing the importance of the mining sector for national development - and the need to redistribute mining revenue to the rest of the country (Larmer 2010, 43-44). While Kaunda did not give in to mining unions' demands for pay rises, the sector itself provided a relatively generous social environment to mine workers and their communities. In 1969, the mining companies were nationalised and subsequently provided free education for the children of miners, subsidised water, housing, and food, and "literally operated 'a cradle to grave' welfare policy" (Fraser 2010, 8-9). Their services benefited the wider areas through 
the maintenance of roads, waste collection, the provision of farm shops, youth skills development schemes, women's clubs, and hospitals (Fraser 2010, 8-9). These spillovers were limited to mining regions, however, where a "labour aristocracy", represented by the unions, was able to exert political pressure (Roberts 1976, 245). Other formal sector workers established unions, too, and the trade union movement in Zambia became a strong political force under UNIP (Rakner 2001). The large majority of informally employed Zambians, however, has remained unrepresented by the unions (Kumitz 2016).

Inequality existed within the agricultural sector, too. Europeans had not only created unions in the mines but also among commercial farmers. During the colonial era, they successfully lobbied the government to protect them from competition from African farmers by creating a Marketing Board that worked in their favour (Chipungu 1987). After independence, the European National Farmers Union became the Commercial Farmers Bureau and later the Zambia National Farmers Union, which retained its base among the bigger, commercially viable farms (Muntemba 1978, 61). Smallholders, for their part, were organised mainly through cooperative structures during the Kaunda presidency (Rakner 2001, 530). While UNIP's origin and support base had been largely urban (Momba 1985, 292), Kaunda encouraged the formation of a cooperative movement and set up a multi-level support structure that assisted smallholders with accessing inputs and marketing their products (Chiwele et al. 1996, 23). Even though theoretically voluntary and bottom-up organisations, the cooperatives remained dependent on support from the state (Chiwele et al. 1996, 23). Politically, too, peasants were dependent on UNIP, which had created them, for communicating their demands to the centre. This avenue crumbled during the 1990s after a change in government and privatisation and liberalisation reforms led to the dismantling of the Marketing Board and cooperative structures. 


\section{Conclusion}

This chapter has zoomed in on Zambia's early post-independence period when high copper prices allowed the government to attempt to remedy the colonial legacies of inequality and a dual economy. The inherited economic structure made this task massive, and efforts were curtailed by an ensuing economic crisis that would last until the end of the century. Looking at the early years allows for a better understanding of the mechanisms by which colonial legacies persisted. This chapter has focussed on two of them. One is the inherited economic structure that has limited economic opportunities and formal work to a minority of Zambians, meanwhile keeping the state vulnerable to world copper prices and, overall, too poor to substantially address the social questions this structure poses. The other is a political one. The lopsided organisation of interests has been a result of, as much as an amplifier of, the socio-economic structure, where workers at the centre were able to pressure companies and the state for social services while those outside the centres have, by and large, remained dependent on a benign state. This makes them more vulnerable to changing ideologies at the centres and ultimately on the willingness of the state to allocate a share of its budget to social assistance.

This short chapter has demonstrated that analyses of present-day African social protection systems need to factor in colonial economic structures. Not only for understanding where social problems of inequality and exclusion come from but also for understanding the range of imaginable political responses to them. If bottom-up demands are not carried into the political arena, the repertoire of policy options at the centre will remain limited to those that are in line with dominant ideologies. Even though social assistance programmes have been significantly scaled up in the new millennium, they reflect what has become taken for granted: the inevitable imperative to save the state costs. While the new social protection agenda of governments and donors reflects a muchneeded return to social questions, they are unsuited to overcome longentrenched legacies of exclusion and marginalisation. Ultimately, the demand for meaningful redistribution and structural transformation will need to be voiced from the bottom up. 
Acknowledgements This chapter is based on the author's $\mathrm{PhD}$ thesis "State Formation after Retrenchment: Social Policy in Zambia", submitted to the University of Bremen in 2020. The research was funded by the Bremen International Graduate School of Social Sciences. The author thanks all her research participants in Zambia, as well as the editors of this book for helpful feedback on an earlier draft. All remaining errors and omissions are her own.

\section{References}

Amin, Samir. 1972. Underdevelopment and Dependence in Black Africa: Origins and Contemporary Forms. The Journal of Modern African Studies 10 (4): 503-524.

Barrientos, Armando, Sam Hickey, Neo Simutanyi, and Denis Wood. 2005. Report of Study on Drivers of Change for a National Social Protection Scheme in Zambia A Study Undertaken for DFID. Lusaka: Department for International Development.

Baylies, Carolyn L., and Morris Szeftel. 1982. The Rise of a Zambian Capitalist Class in the 1970s. Journal of Southern African Studies 8 (2): 187-213.

Bowman, Andrew John. 2011. Disruptive Technologies, Divided Experts: Scientific Knowledge, Development, and the Problem of Stabilising Change, Zambia 1945-2010. PhD Dissertation. University of Manchester.

Chipungu, Samuel. 1987. The State, Technology and Peasant Differentiation in Zambia: A Case Study of the Southern Province, 1930-1987. PhD Dissertation. University of Minnesota.

Chiwele, Dennis K., Pumolo Muyata-Sipula, and Henrietta Kalinda. 1996. Private Sector Response to Agricultural Marketing Liberalization in Zambia: A Case Study of Eastern Province Markets. Uppsala: Nordiska Afrikainstitutet.

Ferguson, James. 1999. Expectations of Modernity: Myths and Meanings of Urban Life on the Zambian Copperbelt. Berkeley and Los Angeles: University of California Press.

Fraser, Alastair. 2010. Introduction: Boom and Bust on the Zambian Copperbelt. In Zambia, Mining, and Neoliberalism: Boom and Bust on the Globalized Copperbelt, ed. Alastair Fraser and Miles Lamar, 1-30. New York: Palgrave Macmillan.

Fraser, Alastair, and John Lungu. 2007. For Whom the Windfalls? Winners and Losers in the Privatisation of Zambia's Copper Mines. Lusaka: Civil Society Trade Network of Zambia and Catholic Centre for Justice, Development and Peace. 
Hinfelaar, Marja, and Jessica Archberger. 2017. The Politics of Natural Resource Extraction in Zambia. ESID Working Papers No. 80.

Kumitz, Daniel. 2016. Nothing about Us without Us: Self-Representation in Social Protection in Southern Africa. Global Social Policy 16 (2): 215-217.

Larmer, Miles. 2010. Historical Perspectives on Zambia's Mining Booms and Busts. In Zambia, Mining, and Neoliberalism: Boom and Bust on the Globalized Copperbelt, ed. Alastair Fraser and Miles Larmer, 31-58. New York: Palgrave Macmillan US.

Lombe, Wilfred C. 2018. Natural Resources, Structural Change, and Industrial Development. Local Content in Zambia-A Faltering Experience? UNU/ WIDER Working Paper No. 118.

Mhone, Guy. 1982. The Political Economy of a Dual Labor Market in Africa: The Copper Industry and Dependency in Zambia, 1929-1969. Madison: Fairleigh Dickinson University Press.

2004. Historical Trajectories of Social Policy in Post-Colonial Africa:

The Case of Zambia. In Social Policy in a Development Context, ed. Thandika Mkandawire, 308-338. New York: Palgrave Macmillan.

Mkandawire, Thandika. 1988. Road to Crisis, Adjustment and

Deindustrialisation: The African Case. Africa Development 13: 5-31.

- 2016. Colonial Legacies and Social Welfare Regimes in Africa: An Empirical Exercise. UNRISD Working Paper 2016-4. Geneva: UNRISD.

Momba, Jotham C. 1985. Peasant Differentiation and Rural Party Politics in Colonial Zambia. Journal of Southern African Studies 11 (2): 281-294.

Muntemba, Maud Shimwaayi. 1978. Expectations Unfulfilled: The Underdevelopment of Peasant Agriculture in Zambia: The Case of Kabwe Rural District, 1964-1970. Journal of Southern African Studies 5 (1): 59-85. Peša, Iva. 2014. Moving Along the Roadside: A Social History of Mwinilunga District, 1870s-1970s. PhD Dissertation. Leiden University.

Putzel, James, and Jonathan DiJohn. 2012. Meeting the Challenges of Crisis States. London: Crisis States Research Centre Report.

Rakner, Lise. 2001. The Pluralist Paradox. The Decline of Economic Interest Groups in Zambia in the 1990s. Development and Change 32 (3): 1-21.

Roberts, Andrew. 1976. A History of Zambia. London: Heinemann.

Seidman, Ann. 1979. The Economics of Eliminating Rural Poverty. In Development in Zambia: A Reader, ed. Ben Turok, 37-48. London: Zed Press. UNCTAD. 2016. Harnessing the Potential for Trade and Sustainable Growth in Zambia. New York and Geneva: UNCTAD. 
Open Access This chapter is licensed under the terms of the Creative Commons Attribution 4.0 International License (http://creativecommons.org/licenses/ by/4.0/), which permits use, sharing, adaptation, distribution and reproduction in any medium or format, as long as you give appropriate credit to the original author(s) and the source, provide a link to the Creative Commons license and indicate if changes were made.

The images or other third party material in this chapter are included in the chapter's Creative Commons license, unless indicated otherwise in a credit line to the material. If material is not included in the chapter's Creative Commons license and your intended use is not permitted by statutory regulation or exceeds the permitted use, you will need to obtain permission directly from the copyright holder.

(c) (i) 